\title{
Art Curriculum: Reflections, Discussions, and Concerns
}

\author{
Cristina Rolim Wolffenbüttel ${ }^{1}$, Lucas Pacheco Brum² \\ ${ }^{1}$ Postgraduate Program Studies in Education (PPGED), State University of Rio Grande do Sul, Brazil \\ ${ }^{2}$ Specialization Course in Music Education, State University of Rio Grande do Sul, Brazil \\ Correspondence: Cristina Rolim Wolffenbüttel, Postgraduate Program Studies in Education (PPGED), State University \\ of Rio Grande do Sul, Brazil.
}

Received: January 16, 2020

doi:10.11114/ijsss.v8i2.4715

\author{
Accepted: January 29, $2020 \quad$ Available online: February 12, 2020
}

URL: https://doi.org/10.11114/ijsss.v8i2.4715

\begin{abstract}
This essay problematizes the resistance processes present in art school curricula. Some curricula are legitimized by the constant emphasis on sequentiality and chronological succession grounded in the history of art, which often comes only from a scholarly conception centered on the work and life of consecrated artists over the centuries, or rereading of works of art. Besides that most of the school curricula are guided by textbooks that legitimize the continuity of these practices, privileging elitist, ideological, sequential aspects that may exclude other artistic manifestations. There is an imposition of good or bad art. There are several discourses in Art that can produce operations and subjectivations of bodies in and out of school, demanding new ways for subjects to be in and out of the classroom in order to produce resistance in curricula and school spaces as a whole. This essay calls these processes urgencies. It is understood that these urgencies are in conflict and have the power to create reliefs with what is legitimized by the school system as a curriculum in Art. In this process, there is a flow of forces between what is put, the status quo and the urgencies, implying lifestyles, aesthetic choices and the construction of discourses, people, bodies, as well as attitudes, actions and ways of walking, speak and behave, that is, ways of managing life that operate in the processes of subjectivation. This essay deals with the resistance that permeates the art curriculum at school, in view of the curricular conceptions already legitimized by the system.
\end{abstract}

Keywords: education, art, curriculum

\section{Introduction}

This essay comes from research and reflection, from some concerns and reverberations that have moved our thoughts around the school curriculum in art. The discussions presented at scientific events are often linked to problematizations about school curriculum conceptions in art not only as a simple curriculum grid composed of contents, concepts, signs and formal codes legitimized by the school canonical device, but as a range of discourses, images, sounds, knowledge, cultural and technological artifacts that operate and subjectify bodies in and out of school - what we call urgencies - in such a way that they produce resistance in the curriculum and in the school space as a whole.

Because of the breadth of the concept of "urgency," which has different meanings and interpretations, it is used in this essay as what is urgent, that is, from what is moving, alive, ephemeral, fast, ubiquitous and mobile. There is talk of the present, the present, the now, the instant. Urgencies are related to media processes, socioeconomic exchanges, informational exchanges, digital mechanisms, interpersonal and interplanetary relationship platforms that are constituted via the web, the unbridled capitalist consumerism of current societies, discourses (visual, sound, textual), the highly seductive still and moving images, the cultural artifacts, the intimate relationships that people establish with mobile phones, ipod, iphones, the ubiquitous subject-and-produce ways, the ways of producing/consuming products, discourses, images, technologies, policies and information, sexual voyage practices via online spaces, student cultures with their diverse tastes and interests, the trite and routinary.

It refers to the urgencies as everything that comes from the spaces in which they live, inhabit and circulate in the students' daily lives, in their bodies and present themselves in the school setting, in the corridors and in the classroom, significant pedagogical practices as well as being part of curriculum building.

This choice is justified because the students who attend today's schools are digital, cyber, subjectivized by a mass culture with devices and products of the highest quality and sophistication that forge, manufacture and impact their lives, bodies, 
discourses, behaviors and thoughts. These fickle urges, however, adhere to subjectivities momentarily reconstructing and modifying them. Polish sociologist Zygmunt Bauman (2001) points to this new "age" as a "liquid society", which would be a replacement from the term "solid" modernity to "liquid" postmodernity, where consumption, fluidity, and artificiality gain space in contemporary societies. A digital age, hypervisualized, or as Raimundo Martins (2006) calls it, a "civilization of images", in which the disturbances of digital life have produced modes of subjectivation in the ways of being, speaking, acting, thinking, behaving and walking.

It is in this movement of urgencies, uncertainties, and influences that invades and stunts the school device that one intends to think about the curriculum, along with the one that is legitimized by the system. Thus, we start from the following question that guides the discussion: how do contemporary urgencies produce resistance in the art curriculum with what is already legitimized by the curriculum and the school device? And yet: what is the pedagogical achievement of the urgencies in the construction and manufacture of the art curriculum?

It is clarified that the purpose of this essay is not to answer this question expressly, but, based on concepts and theories, weave an approximation to the questions, allowing to glimpse possibilities in this sense. In addition, it aims to promote reflections around the art curriculum in school, permeated by what constitutes it and what resists to much to invade and be a part of it.

\section{School Curriculum: Concepts and Reflections}

The curriculum is a cultural, political, social, discursive, democratic, historical artifact of power relations and knowledge that express and guide certain purposes and objectives of the educational system and the formation of subjects. Tomaz Tadeu da Silva (2010) proposes a broad definition of curriculum, which is not constituted as hierarchies, in a static way, but a transitional space curriculum of action that is always in motion and prone to change. A curriculum that allows the political, social, economic and cultural aspects of today's societies to be part of the knowledge built in the classroom, along with those already legitimized by the school device. A curriculum that speaks for itself and has different digital brands from those involved.

The curriculum depends on how it is defined by different authors and theories. In essence, a definition does not reveal what a particular theory thinks what the curriculum is. More important than seeking a definition for the curriculum is knowing which questions a curriculum discourse seeks to answer. Its formation consists of distinct experiences and trajectories of students and teachers. The curriculum is an element of mediation between teachers and students, and between them and knowledge (Silva, 2012).

Another important concept is that of curriculum as fetish, defended by Silva (2010), which sets the scene of discussions around the curriculum, the desires and pleasures that are as drivers of the will to know. It is a curriculum in which the knowledge listed by teachers can be reinterpreted, subject to controversy, conflicted, disagreement and dispute. That is, a curriculum that is always prone to current changes and urgencies. To build and look at a curriculum with a fetish perspective is to understand it as an opportunity to recognize the similarities between the multiple knowledge surrounding the school and the lives of the subjects in the school space.

In other words, it is to bring to its formative steps all the discourses, contents, concepts, themes, sounds, music, images and many other elements often disregarded in the pedagogical planning. This knowledge is found in school corridors, in what students say, do, and propagate silently. It is that knowledge stored in cell phones or other electronic devices that is operating on their bodies and that originates from their cultures. This knowledge intertwined with knowledge already institutionalized in a hierarchical way can be important learning tools, and can greatly help in the process of capturing the interest of students. Silva (2010) explains that conceiving the curriculum as a fetish can be an opportunity to establish ambiguities, contradictions and indeterminations in this artifact, which allows restoring the need for a fetish so that motivation and the achievement of pedagogical objectives can be achieved.

It seems relevant to think of a curriculum as fetish, as students' pleasures, tastes and interests are questioned in such a way that pleasurable learning can be built. Not a pleasure for the object, but a contentment for learning through the object, in an area as rich in possibilities as the teaching of art. This is a challenge for teachers to understand students' lives and what seduces or drives them away. But one may often ask, after all, why do students not seem to enjoy learning in the classroom from what they learn? Or, as research data in Brazil reveal, why do high school students tend to evade before graduation? (Note 1)

In this regard, and according to Paula Sibilia (2012), the novelties present in daily life in recent decades have come to replace much of the existing lifestyle in previous years and, thus, the classroom has come to present itself as a boring space, which is only attended due to the mandatory schooling. Based on the author's reflections, it is understood that the way in which school curricula have been developed and implemented may not be meeting the interests, desires, and needs of students. It seems that the popular, cultural, daily and virtual knowledge, among others, present in the students' lives is 
not being taken into consideration. Content present in various relationship platforms, for example, or in virtual media, which are present in students' lives, which present themselves in different ways, should also be part of the selection of the school curriculum. This universe often seems to "suffocate" the school because it is outside the pedagogical process, and also reflects on teachers in their practices and curriculum development, as many of them seem unable to deal with the digital age, with informational, hyperconnected, interactive networking societies in which cyber students, while performing school assignments, chat in their social networking applications and listen to music.

Sibilia (2012) mentions that, according to research conducted in Brazil, more than $40 \%$ of students between the ages of fifteen and seventeen have ceased to attend school, the main reason being disinterest. From the data of this study, keeping young people in school is not only an economic issue in Brazil, but it is also necessary to understand and create a demand in formal education that corresponds to everything that pervades the contemporary world. The author also emphasizes that the school is presented as outdated and difficult to understand.

Thus, it can be observed that, especially for young people between the ages of fifteen and seventeen, often close to entering the labor market, this approach to curriculum and teaching as a whole may result in dropping out of school. Job opportunities, the way young people learn in virtual spaces of connectivity, access to information and knowledge in different databases, the possibilities to solve daily problems instantly, the different ways of entertainment and the autonomy to manage their lives show the disadvantage that school deals with today. Many students, as research points out, leave school before graduating from high school because the attractions of the labor market and the contemporary are broader, timely and occupy more significant spaces in their daily lives than the time they spend in school.

Thus, the school can no longer account for meaningful learning, and the forms of teaching, positivist, technicist, as well as contentist often do not make sense for most students (Cunha, 2012). In this sense, Sibilia (2012) argues that,

"On the one hand, then, we have the school, like all its classicism on its back; on the other, the increasingly uncontrollable presence of these typically contemporary 'ways of being'. It has become very difficult to avoid such disarticulation by looking at each other, pretending that there is nothing going on, or seeking in vain to mend this artifact which seems to have lost much of its effectiveness and meaning to the world, come across the new landscape that has grown around them" (Sibilia, 2012, p. 15-16).

Among the school, the curriculum, and contemporary students mismatches are perceived, because what is proposed by schools and found in curricula and teaching practices developed in the classroom often has no attractiveness, that is, school and what is taught are not pleasurable. The places where they live and the contemporary world, outside the school walls, are more attractive and seductive. It seems that the crux of the problem lies in the incongruity between what schools expect and want and what students need and expect (Sibilia, 2012).

It is important that in the curriculum there is a space for all these attractive influences and urgencies of the digital age and hyper visualization that are "quietly" found in school, through its walls, corridors and student bodies. It is these influences and urgencies that constantly reconstruct, operate and reproduce the identities and subjectivities of students, which often, in the processes of subjectivation, go unnoticed, or are not taken into consideration by most teachers in their teaching practices. Or even, in some cases, they are viewed by some as bad manners or inappropriate behavior, by the way they walk, behave, and speak, using slang, idioms, and jargons from the television shows they watch, soap operas, songs, and movies preferences.

It is in this movement of urgencies, uncertainties and ways of producing subjects that invade and disrupt the school device, which is thinking about the curriculum, along with what is already legitimized by the system. It is from this that one thinks about a curriculum as an identity (Silva, 1999), not in the solid, fixed and unique sense, but that has its own identity, or rather, the characteristics of its time and those of it will suffer your actions. Silva (2010), contributes to the reflection around these questions. For the author:

"The curriculum has meanings that go far beyond those to which traditional theories have confined us. The curriculum is place, space, territory. The curriculum is power relationship. The curriculum is trajectory, travel, journey. The curriculum is autobiography, our life, curriculum vitae; in the curriculum, identity is forged. The curriculum is text, speech, document. The curriculum is an identity document" (Silva, 1999, p. 150).

Silva (1999) presents a broad definition of curriculum, which is not grounded in heretics or even static, but a transitional, action space curriculum that is always in motion and prone to change and disruption. A curriculum in which the political, social, economic and cultural aspects of today's societies are part of the knowledge built in the classroom, along with those already legitimized by the school device. A curriculum that speaks for itself, and that has different digital touches from those involved.

In other words, the curriculum is what is silenced in the school device because it has no "voice", but that is still there, hidden, needing to be felt, touched, heard, and visualized. It is important to highlight that the "silenced" or "hidden" to 
which this essay refers starts from the assumption of a set of urgencies and knowledge, previously treated, which is "alive" in the school space, but not in pedagogical practices that, producing a thought, a criticism, is in this sense, that this knowledge is silenced "amorphous". About this notion of curriculum and, especially, about hidden curriculum, Silva (2010) explains that it is built by all aspects of the school environment, and that, even without being explicitly in the official curriculum, contributes a lot to the relevant learning. Thus, we approach the conception of a hidden, expanded curriculum that, beyond what is not already apparent, shows an universe of highly seductive internal urgencies inside and outside the school that attract, seduce, and produce students, which is not part of the curriculum explicitly, although should be integrated for they are vital for learning. The hidden curriculum is in all the everyday dimensions of the school in an unplanned way. It is inferred, therefore, that the key point may lie exactly in the urgencies that still exist in schools and classrooms not officially, along with the other formal knowledge already legitimated, but in a hidden way.

\section{Resistances and Legitimacy in the Art Curriculum}

Historically, the school curriculum in art has been limited to a curriculum composed of contents, concepts, signs and formal codes legitimized by established or agreed norms. Many of the curricular conceptions in this field have left out what in this essay is called "urgencies", a concept that is used by the authors based on the uncertainties and changes that contemporary societies face; in other words, from what is movement and what is alive, ephemeral, fast, omnipresent and mobile. As a result, it causes resistance in the curriculum, that is, a flow of forces between what is set, the legitimacy of school art curricula and the urgencies, implying lifestyles, aesthetic choices, and the construction of discourses, of people, of bodies, as well as actions, attitudes and ways of walking, speaking, behaving, and ways of managing life, which operate in the processes of subjectivation, in the construction of subjects.

In this essay, we are interested in highlighting these issues, outlining some challenges that enhance the union between urgencies and formal knowledge already legitimized. However, the ways in which urgencies resist the art curriculum in school are discussed here, considering the curricular conceptions already legitimized by the current system. Thus, it is intended to draw attention to other possibilities for learning and curriculum conceptions in art, which may account for - or at least try - a contemporary culture that seduces, repels, invokes and produces students.

The curriculum is a cultural, political, social, discursive, democratic, historical artifact of power relations and knowledge that express and guide certain purposes and objectives of the educational system and the formation of subjects. Silva (2010) proposes a broad definition of curriculum, which does not consist of heretics, in a static way, but a transitional space curriculum of action that is always in motion and prone to change. A curriculum in which the political, social, economic and cultural aspects of today's societies are part of the knowledge built in the classroom, along with those already legitimized by the school device. A curriculum that speaks for itself and has different fingerprints of the envelopes.

According to Silva (1999), for the curriculum to be what it is, depends on how it was defined by the authors and theories. A definition does not reveal what the curriculum is in essence, but what a theory thinks is a curriculum. More important than seeking a definition for the curriculum is knowing which questions a curriculum discourse seeks to answer. Its formation consists of different experiences and trajectories of students and teachers. According to Silva (2012), the curriculum is an element of mediation between teachers and students, between them and knowledge.

Silva (2010) problematizes the conception of a "curriculum as fetish", which sets the scene of discussions around the curriculum, the desires and pleasures that are as drivers of the will to know. It is a curriculum in which the knowledge listed by the teacher can be (re) interpreted, subject to controversy, conflict, disagreement, and dispute. That is, a curriculum that is always prone to current changes and urgencies. To build a curriculum and conceive it as a fetish is to understand it as an opportunity to recognize the similarities between the multiple knowledge surrounding the school and the lives of the subjects in the school space.

A curriculum in this perspective that recognizes these urgencies implies rethinking other categories and concepts that guide educational thinking. In addition to recognizing and promoting pedagogical practices involving diversity, it is necessary to find the right and necessary union between knowledge, content, and formal codes already legitimized by the system. Nevertheless, even today, following the advancement of curriculum theories, many of the curricular conceptions in art are still imperceptible in schools and classrooms, isolating the world and the school. Many of the teaching practices that focus on disciplinarization, dissociated knowledge, epistemological fragmentation, blocks of syllabus, emphasis on the use of textbooks, serialization, technique and expressive approaches to art teaching are focused on an older heritage, such as the early twentieth century, in Brazil, for example, when the still modernist tradition reigned. With these influences, the idea of art as a free expression was transposed into the educational field. And, as a result, in this favorable context of the 1970s, the discipline Artistic Education was consolidated and became compulsory in formal education, starting from Law No. 5.692/1971, which introduced Artistic Education in school curricula of basic education.

With this conception of Modern Art, which had a provocation of academic art, which until then was realized in Brazil, 
from European and neoclassical precepts, with Modernism, we sought a new expression, which was genuinely national and a liberation of aesthetics closely linked to European and academic standards. From this movement in search of a Brazilian art, the teaching of art was marked by free expression, similar to the expression of children, in other words, their feelings and desires. In the conception of the time, art did not need to be taught, but expressed by the students. Based on these assumptions, experiments were conducted in the second half of the twentieth century in the teaching of art to children and adolescents with very interesting extracurricular activities.

This heritage left by Modernism has still affected most curricular conceptions in art today, with a curriculum based only on sequentiality and chronological succession based on Art history, with a scholarly vision focused on the work and life of consecrated artists throughout the centuries. Many of the teaching proposals present the rereading of works of art by renowned artists, privileging aspects of an elitist, ideological "art" of historical sequences, which therefore excludes other artistic manifestations and art forms.

Legitimate such a homogeneous and Eurocentric curriculum conception in a perspective of linear evolution of history, besides being generalist, assumes only one great truth and a single discourse, marginalizing other art forms and a huge field of knowledge that students live daily, the urgencies. A hegemonic curriculum is dominant because it controls, regulates, and governs who is allowed to speak, and what to speak about, which works, artists, and movements in Art history. Marginalizes and renders illegitimate other art forms, cultural artistic manifestations and artistic expressions such as popular culture, black, indigenous and gay culture, etc. This implies that most of the speakers are white men and women who have the consent to give a résumé address on these subjects. It often does not legitimize blacks, indigenous or gay, who are traversed by their own black, indigenous, and gay experiences. And when these artistic manifestations of these cultures appear in the curriculum, they occupy reduced or minimized spaces, close to classical art.

They are, therefore, forms of transmission and regulation of hegemonic knowledge and truths that often do not deal with minorities. In addition, the peers do not recognize each other. However, we share the conception of a curriculum that breaks the epistemological bonds and the fragmentation of knowledge, giving priority to the interests and desires of the students in their construction. Given this, it is important, as Foucault (2005, p. 28) says, "to shake the stillness with which we accept certain discourses." It is necessary to break with old curricular conceptions and some "truths" that are still present in the school environment. More than breaking with truths, it is important to understand them as they became true and to make a movement of opposing forces to seek new conceptions of curricula and to challenge the truths inherited from modernism. In the perception of Duncum (2011),

"The curriculum should therefore be based on the nature of visual culture, specifically on students' experiences related to it and integrated into the teacher's knowledge. While the modernist curriculum was based on a linear structure, ranging from simple to complex, spanning elements and principles of history and themes, a curriculum that mirrors the rhizomatic structure of visual culture will begin from any point with an image or gender, the representation of a theme, a controversy or a question" (Duncum, 2011, p. 22).

Duncum (2011) conceives the curriculum from the perspective of visual culture as rhizomatic, that is, a curriculum that has no middle, beginning or end. Not in the sense that it does not have a goal and direction, but rather a curriculum that goes toward the interests and desires of the students, being the same assets and proponents of their own knowledge. But that does not mean that formal knowledge of art, which is already legitimized, will not be part of the curriculum. This presupposes thinking of a curriculum without hierarchies between themes, codes, images, and concepts without considering some more important than others. Therefore, it is understood the pertinence of thinking and problematizing the curriculum from the perspective of art teaching, since this field encompasses everyday representations in the most diverse segments, including cinema, television, fashion, advertising, literature, books, social networks, entertainment sites, among many others, the cultural artifacts, the ways of seeing, aesthetic experiences, and the meanings we produce with the culture from the visualities in which students live daily.

It is pertinent, then, to design an emergency art curriculum, where these come from specific places in each cultural context. This thinking is in line with the propositions of Larrosa (1994), Steinberg \& Kincheloe (2004), that the pedagogical is beyond the institutionalized curriculum and the places that have the function of educating, such as the school, the church, or the family, for example. But also other broader places and spaces in which education takes place, such as movies, television, advertising, fashion campaigns, video games, comic books, sticker albums, magazines, books, the internet, social media, relationship platforms, and more, in which power is organized and diffused (Steinberg \& Kincheloe, 2004). They are territories of education and subject formation, in which the knowledge produced by these places is often outside the school and curriculum, causing incongruities between what students learn in school and what they live trivially in the spaces where they reside. Urgencies, therefore, are pedagogical, as they shape and produce subjects, truths, discourses, bodies, or thoughts. The character of pedagogy, in this perspective, is not hegemonic or monopolizing, focusing on specific poles such as school and family. Pedagogy is now in different places of contemporary culture, which is permeated 
by relations of knowledge and power.

Kerry Freedman (2008) argues that the curriculum has a number of places in and out of school, not just in the professional community of the discipline. The author explains that external references, such as the diversity of texts and images, may be more important for students' understanding than a sequence-based curriculum of Art History content, for example. The author further infers that school curricula try to filter ideas and experiences seen as legitimate content. By filtering experiences, preferences, desires, ideas, and perceptions we filter the pedagogical of what is outside the curriculum, and added to what is inside, what is already legitimized, that way producing a curriculum of effects, or as Silva (2010) highlights, a curriculum as a fetish.

It seems useful to take urgencies as pedagogical, since they are presented as power relations in a process of value transmission (Silva, 2000). In addition to producing truths, behaviors, discursive practices, and ways of being in the world, acting on students and people in different ways, and transforming experiences. They impose, seduce, attract, dominate, subject them, educate, form, inspire, repel, lie, summon, and forge.

Urgencies are thus entangled in the power and knowledge relations that students produce and manufacture. In Foucaultian thought, knowledge and power are not external to each other; they act in related forces and depend on each other. However, these spaces produce knowledge and power because power is in motion from "strategic power relations sustaining and being sustained by types of knowledge" (Foucault, 1979, p. 246). Power, thus, in the philosopher's conception, is not something massive, tangible, hierarchical but something that is established in the different social layers from relationships, and everyone is under its actions, and cannot be outside of power relations. Thus, power is intangible, operative and ubiquitous, and everyone is under its actions, as Deleuze (2008) points out, power is strength, not form.

These urgencies are ubiquitous locus. They educate and form subjects in their most varied senses. These urgencies not only drive students, but also produce discourses, meanings, and truths about them. So why not take urgencies into a potent fusion of curricular art with formal knowledge already legitimized by the school system? A fusion, in this sense, could start from what students already know, and then move to new content they are not familiar with yet, in a transdisciplinary way. The curriculum would then take on different prints and could be changed, remodeled, and trimmed according to its needs. Thus, perhaps this would diminish the gap between the legitimacy of the art curriculum in school and the urgencies that exist inside and outside of it, as well as build a curricular discourse that represents particular truths, not a monopolizing curricular discourse.

It is the fusion of what already exists in the curricula of high intellectual and cultural content with the urgencies of the contemporary world and those of students. Thus, it is not a matter of denying or neglecting erudite knowledge, content, and formal concepts. Nor they erase them from the curriculum, but rather promote mergers that foster pleasurable learning from the urgencies that permeate students, something so dear and crucial for teachers. On the other hand, we are careful not to put emphasis only on "open" curricula in emergencies because there is a risk that the curriculum is just something fun (Carlson \& Apple, 2003) present in the contemporary world. But let teachers be able to look at their time, building a curriculum relevant to the interests and the universe of students (Carlson \& Apple, 2003).

This implicates challenges and difficulties for teachers; that is, the curriculum is not monolithic, centered on textbooks, artists, works of art, and art history, rather, it is dynamic. It means problematizing the processes that occur inside or outside the classrooms and schools because from a wide universe of knowledge and, one selects what will constitute the curriculum, in other words, all choice is power. Silva (2001) explains that the curriculum is knowledge linked to power. Power is not something that, from the outside, determines what form the knowledge inside the curriculum will take. Power is inscribed within the curriculum. The power in it is in the choices and decision making of content, knowledge, themes, concepts, images, music, texts, attitudes, actions, values, moralities, discourses, approaches and methodological procedures, for example, that will be part of the curriculum. This is what promotes segregation. It is what it includes or excludes. Power in the curriculum can be characterized in what is legitimized as knowledge, in what is or is not considered as art. They are inclusions and exclusions not only of knowledge, but also of social groups, people, issues such as race, gender, classes, ethnicity or religion (Silva, 2001).

Thus, every choice is exclusionary because "in any way and under any conception, when talking about curriculum, we are talking about power" (Silva, 1999, p. 53). "Curriculum theories, having decided which knowledge should be selected, seek to justify why 'this knowledge' and not 'that knowledge' should be selected" (Silva, 1999, p. 15). With this, it is believed that the curriculum is the result of a selection. Selecting is an operation of power and in every choice and selection there is an ideological intention, which is not neutral.

The school is a space where power operates and produces knowledge, and knowledge produces power (Foucault, 1979). It is a daily negotiation of space for dispute, for such contemporary attractions, as well as trivial knowledge, are what will bring learning to life and create a sense of pleasure as students learn alongside the institutionalized content. Thus, the curriculum assumes a discourse and a truth of a place, and of very specific subjects who identify themselves, but are 
always open to change or diverge within the discourse itself.

Power is also exerted within the curriculum from a set of content, codes, knowledge, concepts, which will be taught and discussed in the classroom, since we choose certain content, concepts, and codes for pedagogical practices, they are creating truths, subjects, bodies, thoughts, actions, and conduct. However, the choices made in classroom curricula and practices are not neutral in the making of subjects, discourses, and behaviors. In this process, subjects are constantly being manufactured and produced in the classroom, based on choices and decision making. Power, in this conception, is seen more as a constructive and productive rather than repressive network.

Power also operates in resistance, for one of the effects of power is force, since where there is power there are reaction poles. Contemporary urgencies resist the curriculum, no matter how quietly, and they try to be part of the curriculum, they operate in the subjectivation processes of students. However, resistances are effects of forces contrary to what is selected and legitimated by the system, and have art status in the curriculum. The curriculum can be a space of resistance because it is necessary not to succumb to the urgencies, not in the sense of denying them, but facing them, bringing them into the arena of dispute of what is institutionalized and legitimized. Silvio Gallo (2004, p. 90) argues that "resistance does not come from outside, it is not outside power, but it is part of the very game of its existence", in this case, it is within the game of what is legitimated by the curriculum, "[...] a power is defined only in relation to one or several counterpowers the resistance".

Michel Foucault (1979) warns that power is first and foremost freedom, so resisting is one of the effects of power. Thus, the urgencies only resist the school and the classroom because they have freedom, whether through power relations and in action. Resistance does not come from outside nor is it external to power; on the contrary, it is within its own game of existence, in this case, the positions that urgencies take within the school and curriculum, tensing and producing forces with the status quo already legitimized.

Although schools and their curricula often have different difficulties, due to multiple factors such as political and economic interests, as well as pedagogical interests, it is necessary to open loopholes, fractures, cracks in the face of negotiations, conflicts and "the forces", so that it is possible to enhance pedagogical practices and local curricular discourse. Addressing the urgencies of the present and what is said about students means dealing with power/knowledge relations that form and educate them.

\section{Conclusions}

The curriculum thus produces meanings and connotations in their daily lives and in relation to the social problems faced by contemporary societies. The curriculum is produced and acts in different ways and meanings with different lines and interpretations, with everyone involved, who can divert, subvert, and contest them. The curriculum is a social relationship that produces effects on the people involved, in which the construction of knowledge occurs in the relationship among people. In this process of construction and production are involved the divergent power relations that operate in the bodies and processes of subjectivation. The discourses and the curricular truths built that form the students, not only as a school formation, but as beings of existences and subjectivations.

Thus, according to Silva (2001, p. 194), it is "important to see the curriculum not only as being built from doing things, but also seeing it as doing things to people. The curriculum is what we teachers and students do with things, but it is also what the things we do for us". Curriculum is action and causes effects that teachers, students, and the school community produce and in turn present themselves in identity, critical, political, cultural, and social modes. The curriculum builds and reproduces particular and specific subjects. By selecting, choosing, legitimizing, and delegitimizing art in the curriculum, it "makes us what we are" (Silva, 2001, p. 196). This justifies the importance of opening spaces for the contemporary urgencies of hyperconnectivity that shape human life, as they have an effect on us and on students who are reflected in the often neglected school and curriculum. In this regard Silva (2001, p. 194) states that "if by producing the curriculum we are also produced, it is because we can be produced in very particular and specific ways. And these forms depend on specific power relations. Flagging and identifying them is thus a fundamentally political action".

It is in this perception that the reflection around the art curriculum is proposed, that is, a curriculum that produces effects and that constitutes what is accomplished in the school in a way implicated in the dynamics of action, politics and affections, pleasures, tastes, interests, and attraction and that "bewitches" its authors, in other words, it has digital traces of all in its construction and in its pedagogical process. Thus, it is configured with an identity, with individual characteristics of each context in which it is inserted from the contemporary urgencies that surround them.

The art curriculum is understood as a discourse and as a very particular cultural artifact that produces particular truths as well as constituting particular subjects. It is involved in the relations of power, knowledge and the constitution of positions, so that the notion and conception of curriculum are in the dynamics of the urgencies of digital life and the contemporary attractions that permeate the societies in the fusion of legitimate content and formal codes by the school device. 
Therefore, a conception curriculum of art with diverse perspectives is defended, which is based on the investigation and the creation, and that includes all the questions, such as social, cultural, economic, and political problems of contemporary societies. A curriculum of urgencies that is configured as a productive, meaningful, enjoyable, and social justice practice, in which students recognize themselves not only as authors of the curriculum, but of their own learning, becoming critical, emancipated subjects who know how to live, and solve problems in the spaces where they live.

\section{Acknowledgements}

Eduardo Filipe Albrecht Lassig, Rio Grande do Sul Research Support Foundation (FAPERGS), National Council for Scientific and Technological Development (CNPq).

\section{References}

Bauman, Z. (2001). Modernidade líquida. Rio de Janeiro: Jorge Zahar.

Carlson, D., \& Apple, M. (2003). Teoria educacional crítica em tempos incertos. In Hypolito, A. M.; Gandin, L. A. (Ed.), Educação em tempos de incertezas. Belo Horizonte: Autêntica, pp. 11-57.

Cunha, S. R. V. da (2012). Questionamentos de uma professora de arte sobre o ensino de arte na contemporaneidade. In Martins, R.; \& Tourinho, I. (Ed.), Cultura das imagens: desafios para a arte e para e educação. Santa Maria: Ufsm, pp. 99-123.

Deleuze, G. (2008). Conversações. São Paulo: 34.

Duncum, P. (2011). Por que a arte educação precisa mudar e o que podemos fazer. In Martins, R.; Tourinho, I. (Ed.). Educação da cultura visual: conceitos e contextos. Santa Maria: Ufsm, pp. 15-30.

Foucault, M. (1979). Microfísica do poder. Rio de Janeiro: Graal.

Foucault, M. (2005). Arqueologia do saber. Rio de Janeiro: Forense Universitária.

Freedman, K. (2008). Currículo dentro e fora da escola: representações da Arte na cultura visual. In Barbosa, A. M. (Ed.), Arte-educação contemporânea: consonâncias internacionais. São Paulo: Cortez, pp. 126-142.

Gallo, S. (2004). Repensar a Educação: Foucault. Educação e Realidade: Dossiê Michel Foucault. Porto Alegre, 29(1), 79-97. jan/jun.

Larrosa, J. (1994). Tecnologia do eu e educação. In Silva, T. T. da. O sujeito da educação: estudos foucaultianos. Petrópolis: Vozes, pp. 35-86.

Martins, R. (2012). Porque e como falamos da cultura visual? Visualidades, $4\left(\begin{array}{lll}1 & \text { e } & 2\end{array}\right)$. https://doi.org/10.5216/vis.v4i1ei2.17999

Sibilia, P. (2012). Redes ou paredes: a escola em tempos de dispersão. Rio de Janeiro: Contraponto.

Silva, T. T. da (2001). Currículo e identidade social: territórios contestados. In Silva, T. T. da. Alienígenas na sala de aula: uma introdução aos estudos culturais em educação. Petrópolis, Rio de Janeiro: Vozes, pp. 190-207.

Silva, T. T. da (2010). Currículo como fetiche: a poética e a política do texto curricular. Belo Horizonte: Autêntica.

Silva, T. T. da (1999). Documentos de identidade: uma introdução às teorias do currículo. Belo Horizonte: Autêntica.

Silva, M. R. da (2012). Perspectivas curriculares contemporâneas. Curitiba: Ibpex.

Steinberg, S., \& Kincheloe, J. (Ed.) (2004). Cultura infantil: a construção corporativa da infância. Rio de Janeiro: Civilização Brasileira.

\section{Notes}

Note 1. According to data from the National Institute of Educational Studies and Research Anísio Teixeira (INEP), no Brazilian state reached the IDEB target in 2017 in High School (http://portal.inep.gov.br).

\section{Copyrights}

Copyright for this article is retained by the author(s), with first publication rights granted to the journal.

This is an open-access article distributed under the terms and conditions of the Creative Commons Attribution license which permits unrestricted use, distribution, and reproduction in any medium, provided the original work is properly cited. 